\title{
Character association studies in grape accessions selected from Leh district of Jammu and Kashmir
}

\author{
Tsering Dolkar, M. K. Sharma and Amit Kumar* \\ Division of Fruit Science, Sher-e-Kashmir University of Agricultural Sciences \& Technology-Kashmir, Shalimar, \\ Srinagar (J\&K), INDIA \\ *Corresponding author. E-mail: khokherak@rediffmail.com \\ Received: October 5, 2016; Revised received: March 18, 2017; Accepted: August 22, 2017
}

\begin{abstract}
Characters association and path analysis was studied in fifty genotypically diverse grape (Vitis vinifera L.) accessions for 20 important quantitative characters. The genotypic and phenotypic association of yield was significantly positive with most of the studied characters except yield efficiency, berry weight and chemical characters. Yield was positively and significantly correlated $(r)$ with bunch length $(0.652)$, bunch breadth $(0.584)$, bunch weight (0.946), number of bunches per vine (0.289), number of berries per bunch $(0.672)$, berry length $(0.337)$, berry breadth (0.363) and number of seeds per berry (0.612). Direct and positive effect was observed between yield and bunch and berry characters. Bunch breadth (1.538), number of bunches per vine (0.708), berry weight (1.112) exhibited a good amount of direct effect on yield and its correlation with yield was also positive. Hence it is clear from the present study that for selection of any accession in the crop due emphasis must be given on the yield and the associated characters which have direct and positive effect on the yield.
\end{abstract}

Keywords: Accessions, Character, Correlation, Grape, Path coefficient, Variability

\section{INTRODUCTION}

Knowledge of interrelationship between yield and its components is useful, if selection for simultaneous improvement in these characters is to be effective. As more variables are included in the correlation study, the association becomes more complex, in such situation, path coefficient analysis was devised which provides effective means of finding out direct and indirect causes of association and permits a critical examination of the specific forces acting to produce a given correlation and measures the relative importance of each casual factor. Since yield is a complex trait, governed by a large number of component traits, it is imperative to know the interrelationship between yield and its component traits to arrive at an optimal selection index for improvement of yield (Obasi, 1992).

Grape is unique, not only as a major global horticultural crop but also because of its ancient historical connections with human culture development as grape was one of the oldest fruit crop (Galet, 2000; Clarke, 2001) to be cultivated by man to produce table fruits, dry fruits, juice and wine (Frederique Pelsy et al., 2010). More than 9,600 grape cultivars exist around the world (Galet, 2000) and as per international variety catalogue almost 16,000 prime names appear in the genus Vitis (Maul and Eibach, 2003). The area under grape cultivation in India is 118.7 thousand hectares with production of 2585.3 thousand MT (NHB, 2015), however, Jammu and Kashmir produces 1299 MT of grapes from an area of 315 ha (Anonymous, 2016). Under dry temperate region of Jammu and Kashmir the maximum area is in lower belt of Leh district (Angchok et al., 2009). During the early period, when Ladakh was the transit point on the Central Asian trade route, the traders, nomads and invaders from Yark and Baltistan, Punjab, Kashmir, China and Tibet used to pass through this region (Jolden, 2012) and the grape vines got disseminated or introduced in the lower belt of Leh district. The species of grapes are quite heterozygous and seedling off-springs exhibit wide genetic variability not only in fruit quality but also in vegetative vigour. Because of these variations, seeds are not used for propagation of vines meant for commercial purpose (Adsule and Upadhyay, 2004).

As grape is an important fruit crop of dry temperate zone of Ladakh region and presence of high level of genetic diversity makes selection an efficient method of improvement in grape. For this reason, the present study was conducted to observe the relative association of some of the important vine characters contributing directly and indirectly to fruit yield and other quality characters in grape.

\section{MATERIALS AND METHODS}

Out of a large population from five different villages, fifty accessions were selected for further study (Table 1).

The accessions were selected and marked on the basis 
of health, vigour, bearing habit and desirable berry characters. All the marked vines were of seedling origin ranging between age of 20 to 60 years. Observations were recorded on vegetative, foliage, fruit physical and chemical characters. Data was recorded on the various characters viz. cane length $(\mathrm{m})$, cane diameter $(\mathrm{cm})$, internodal length $(\mathrm{cm})$, leaf area $\left(\mathrm{cm}^{2}\right)$, yield $(\mathrm{kg} /$ vine). Yield efficiency was calculated as per Westwood (1993).

Yield efficiency $\left(\mathrm{kg} / \mathrm{cm}^{2}\right)=$ Yield / Trunk cross sectional area

Where, Trunk cross sectional area $($ TCSA $)=\operatorname{girth}^{2} / 4 \pi$. With respect to bunch and berry physical characters viz. bunch length $(\mathrm{cm})$, bunch breadth $(\mathrm{cm})$, berry length $(\mathrm{cm})$ and berry breadth $(\mathrm{cm})$ were observed with the help of vernier caliper. For these characters, randomly ten bunches and ten berries were taken from the vines. Randomly selected samples were subjected to bunch weight $(\mathrm{g})$ and berry weight $(\mathrm{g})$ with the help of digital weighing balance. All bunches from the vine were counted and number of bunches per vine were observed while for number of berries per bunch randomly ten bunches were taken and counted. Number of seeds per berry was also observed. Chemical characters viz. $\mathrm{TSS}\left({ }^{\circ} \mathrm{B}\right)$, acidity $(\%)$, total sugars $(\%)$, TSS/ acid ratio and juice content $(\%)$ were observed as per the standard procedure as given in AOAC, (1998). The genotypic and phenotypic coefficients of variation were worked out as per procedure described by Singh (2003). The path analysis was carried out following Dewey and $\mathrm{Lu}$ (1959).

\section{RESULTS AND DISCUSSION}

High level of genotypic influence and lesser environmental effect on the characters expression was evident from the higher value of genotypic correlation coefficients $\left(r_{g}\right)$ (Table 2 ) compared to phenotypic correlation coefficients. A highly significant and positive correlation at genotypic level was observed between cane length and yield (0.356) and bunch length (0.356), however with bunch weight, cane length was highly significant and positive correlated both at genotypic (0.447) and phenotypic (0.436) level. At both genotypic and phenotypic level, a negative and but highly significant correlation was recorded between cane length and yield efficiency $(-0.520$ and -0.408 , respectively), which clearly indicates that the yield efficiency was correlated with cane diameter and not with cane length. Cane diameter had positive and highly significant correlation against leaf area (0.389 and
0.368 ) at both level. Larger the leaf area more will be the photosynthesis which results to more vigorous vines (Joshi et al., 2015). Yield showed positive and highly significant correlation at genotypic and phenotypic level with bunch length (0.652 and 0.604), bunch breadth (0.584 and 0.519$)$, bunch weight $(0.946$ and $0.895)$ and number of berries per bunch $(0.672$ and $0.597)$. Berry breadth (0.363) and number of seeds per berry $(0.612)$ were also highly significantly and positively correlated with yield at genotypic level. Simple and positive correlation was noticed between yield and number of bunches per vine (0.289) and berry length $(0.337)$ at genotypic level whereas between yield and berry length $(0.320)$, berry breadth $(0.349)$ and number of seeds per berry (0.315) which depicts that all these characters are yield contributing characters. High significant correlation was recorded between number of bunches per vine and yield (Joshi et al., 2015).Yield efficiency reported positive and highly significant correlation with number of bunches per vine (0.377), while a negative and simple correlation was noticed between yield and berry breadth $(-0.278)$ and berry weight (-0.308). Kliewer and Dokoozlian (2000) and Gupta et al. (2015) also reported positive and significant correlation of yield with bunch length, bunch breadth and bunch weight.

Positive and highly significant correlation was recorded at both genotypic and phenotypic level between bunch length and bunch breadth (0.953 and 0.804), bunch weight $(0.727$ and 0.692$)$ and number of berries per bunch $(0.421$ and 0.343$)$ resulting in getting high yields (Branislava et al., 2011 and Joshi et al., 2015). Bunch length and number of seeds per berry showed simple and positive correlation at genotypic level (Table 2). Highly significant and positive correlation was observed between bunch breadth and bunch weight $(0.639$ and 0.578$)$ at both genotypic and phenotypic level, while with number of seeds per berry (0.404) at only genotypic level. Bunch breadth was positively correlated with number of berries of bunch (0.294), berry breadth (0.299) and berry weight (0.309). Both at genotypic and phenotypic level, bunch weight showed positive and highly significant correlation with number of berries per bunch $(0.647$ and $0.575)$, berry length $(0.383$ and 0.372$)$, berry breadth $(0.430$ and 0.419$)$ and number of seeds per berry (0.648 and 0.385$)$. The bunch weight considered to be an important trait contributed significantly towards fruit yield and quality of grapes. Selection based on bunch weight may result in selection of high yielding

Table 1. Geographical feature and number of samples selected from different villages.

\begin{tabular}{|c|c|c|c|c|c|}
\hline S. N. & Name of the village & Latitude & Longitude & Altitude & Number of samples \\
\hline 1 & Warseedo & $34^{\circ} 30^{\prime}$ & $76^{\circ} 42^{\prime}$ & 3414 & 04 \\
\hline 2 & Achinathang & $34^{\circ} 31^{\prime}$ & $76^{\circ} 42^{\prime}$ & 3480 & 21 \\
\hline 3 & Yokmathang & $34^{\circ} 32^{\prime}$ & $76^{\circ} 39^{\prime}$ & 3401 & 07 \\
\hline 4 & Hanuthang & $34^{\circ} 34^{\prime}$ & $76^{\circ} 37^{\prime}$ & 3372 & 05 \\
\hline 5 & Dha & $34^{\circ} 39^{\prime}$ & $76^{\circ} 28^{\prime}$ & 3361 & 13 \\
\hline
\end{tabular}


Tsering Dolkar et al. / J. Appl. \& Nat. Sci. 9 (3): 1782 -1786 (2017)

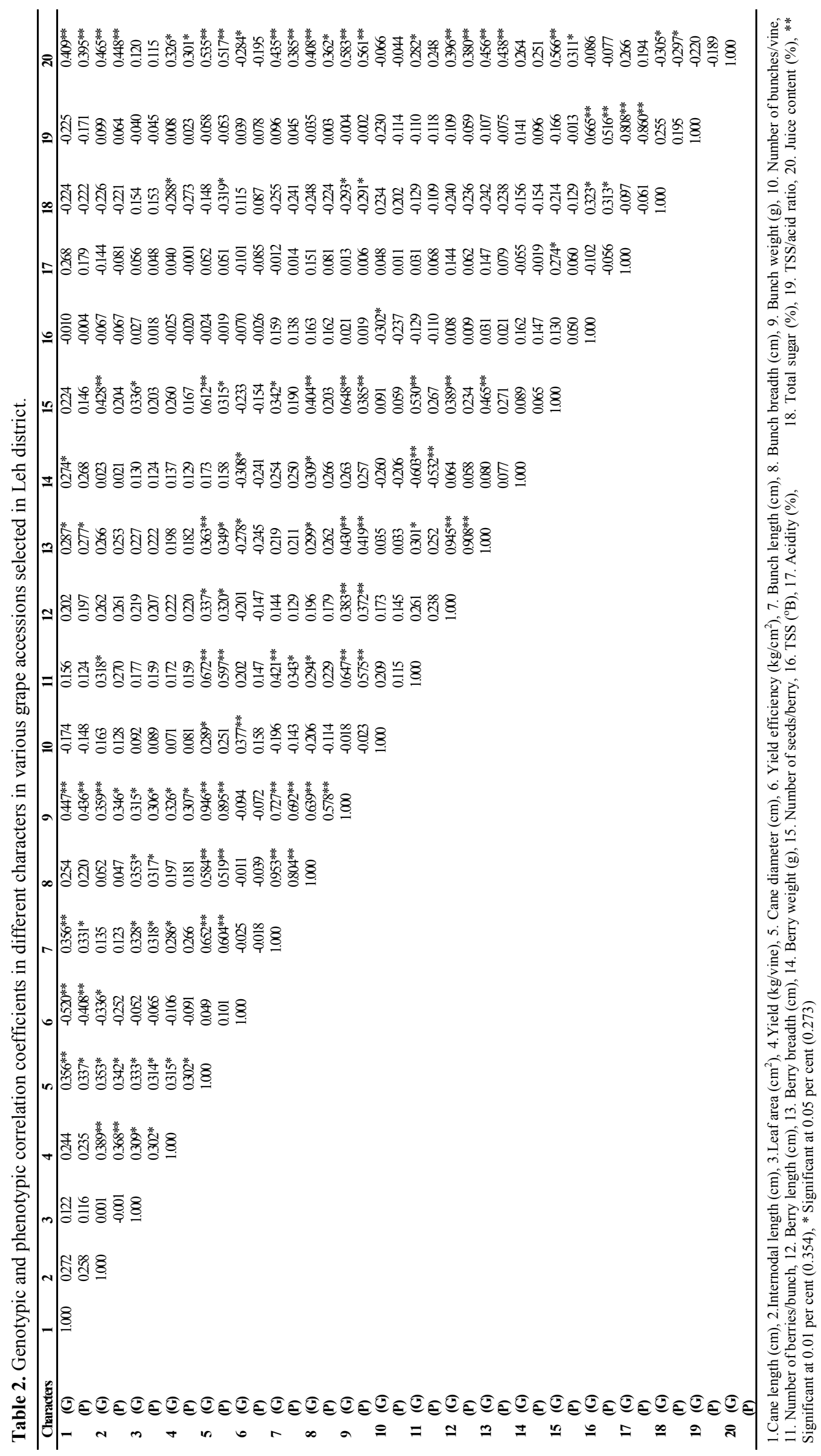




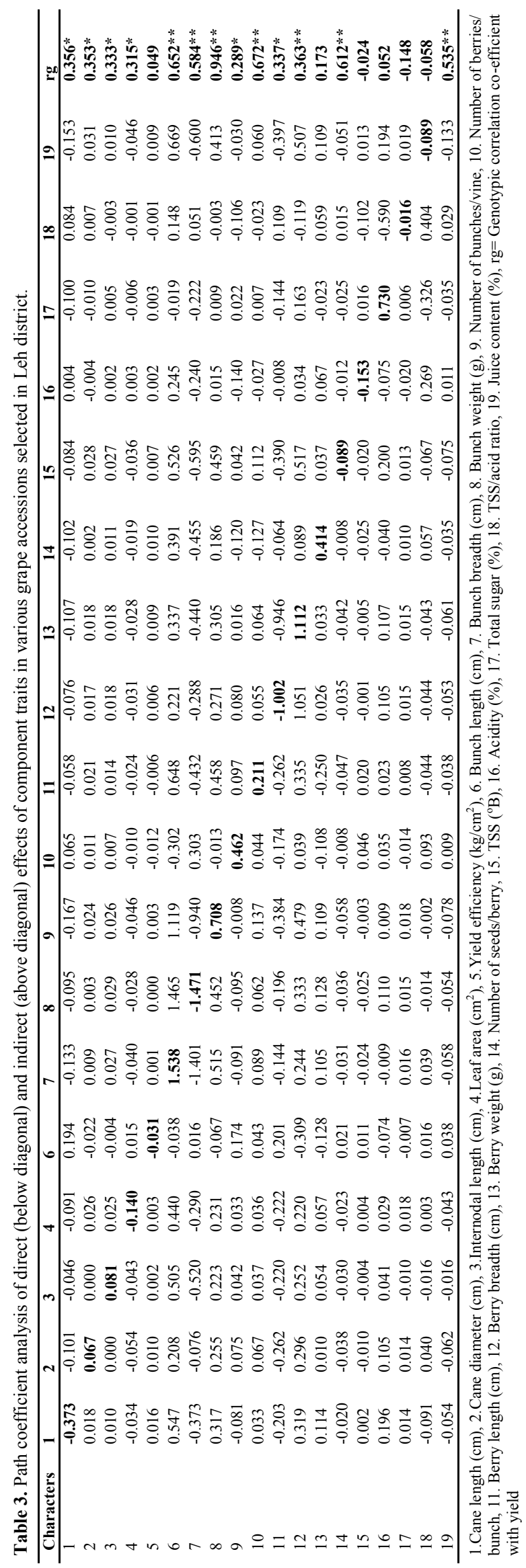

vines (Branislava et al., 2011). Bunch weight showed negative correlation with total sugar (-0.293 and 0.291 ) at genotypic and phenotypic level.

A highly significant but negative correlation at both genotypic and phenotypic level was observed between number of berries per bunch and berry weight $(-0.603$ and -0.532). It indicated that improvement of berry weight will reduce the number of berries per bunch (Gupta et al., 2015). Positive correlation was noticed for berry breadth (0.301) and number of seeds per berry $(0.530)$. Berry length and berry breadth showed highly significant and positive correlation with number of seeds per berry ( 0.389 and 0.465$)$ at genotypic level only whereas berry length was positively and highly significantly correlated with berry breadth at genotypic (0.945) and phenotypic (0.908) level. Total soluble solids were positively correlated with total sugars both at genotypic (0.323) and phenotypic (0.313) level, whereas TSS showed highly significant positive correlation with TSS/acid ratio (0.665 and 0.516$)$ at both level. Significant negative association of berry length, berry breadth and berry weight with total sugars indicated that improvement of these traits through selection will also improve the quality of grapes.

Acidity was highly but negatively correlated with TSS/ acid ratio (-0.808 and -0.860$)$ at both genotypic and phenotypic level (Table 2). Juice content showed highly significant and positive correlation at both levels with most of studied characters viz. cane length $(0.409$ and 0.395$)$, cane diameter (0.465 and 0.448$)$, yield (0.535 and 0.517), bunch length (0.435 and 0.385$)$, bunch breadth $(0.408$ and 0.362$)$, bunch weight $(0.583$ and 0.561$)$, berry length (0.396 and 0.380$)$, berry breadth $(0.456$ and 0.438$)$ and number of seeds per berry $(0.566$ and 0.311$)$, whereas juice content was negatively correlated with yield efficiency $(-0.284)$ and total sugars $(-0.305)$. These results are in conformity with those reported by Kumar et al. (2002) and Gupta et al. (2015) who advocated that the importance should be given to bunch length, bunch breadth, number of bunches per vine, number of berries per vine berry weight during selection process because these characters contribute towards the yield.

Path coefficient analysis is a method of investigating such cause and effect relationships through portioning correlation into direct and indirect effects. For path analysis at the genotypic level yield per vine was taken as dependent variable and all other traits used for correlation wereconsidered as causal variables. The perusal of path analysis presented in Table 3 revealed that bunch length has direct and positive effect on bunch breadth (1.538), however, negative and direct effect was noticed between bunch breadth and bunch weight (-1.471). Highly positive and direct effect was also recorded between bunch weight and number of bunches per vine (0.708), number of bunches per vine and number of berries per bunch $(0.462)$, berry breadth and 
berry weight (1.112) and acidity and total sugar $(0.730)$. The correlation of cane diameter $(0.356)$, cane diameter (0.353), bunch length (0.652), bunch breadth (0.584), bunch weight (0.946), number of bunches per vine (0.289), number of berries per bunch (0.672), berry length $(0.337)$, berry breadth $(0.363)$, number of seeds per berry $(0.612)$ and juice content $(0.535)$ with yield was positive and their direct effect on yield was also positive. Gupta et al. (2015) also reported that bunch length as well as bunch breadth contributed to yield per vine indirectly via bunch weight.

The present results suggested that due emphasis should be given to the accessions that are having maximum number of bunches per vine, bunch length, bunch breadth, bunch weight, number of berries per bunch, berry length, berry breadth, berry weight in the selection process due their high positive effect on yield. The remaining characters also exerted considerable effect on yield revealing the scope for considering these traits in selection.

\section{Conclusion}

The correlation $(r)$ studies with 50 accessions of grapes revealed the importance of number of bunches per vine, number of berries per bunch, bunch length, bunch weight and berry weight in determining the total yield. The path coefficient analysis brought out the number of bunches per vine, bunch length, bunch breadth, bunch weight, berry weight as major yield component. Hence a perusal of correlation and path analysis studies of the present investigation revealed the number of bunches per vine, bunch length, bunch breadth, bunch weight, berry length, berry weight are highly important yield components of having direct bearing on improvement of yield and quality of grapes.

\section{REFERENCES}

Adsule, P.G. and Upadhyay, A. (2004). Grape cultivation on rootstocks. NRC for Grapes, Pune. Pp. 22

Angchok, D., Diwedi, S.K. and Ahmed, Z. (2009). Traditional foods and beverages of Ladakh. Indian $J r$. Tradit.Knowl.8(4): 551-558.

Anonymous (2016). District wise area and production of major horticulture crops in Jammu and Kashmir state for the year 2015-2016. Department of Horticulture, J and $\mathrm{K}$ Govt.

A.O.A.C. (1998). Official Methods of Analysis. Association of Official Analytical Chemists, Washington, DC.

Branislava, S., Nevena, P., Zorica, R.V., Dragica, R., Ana, V. and Mirjam, V. (2011). Effect of the genotypeenvironment interaction on phenotype variation of the bunch weight in the white wine varieties. Arch. Biol. Sci. 63(2): 365-370

Clarke, O. (2001). Encyclopedia of grape. Orlando: Harcourt Books., 91-100

Dewey, D.R. and Lu, K.H. (1959). Correlation and path coefficient analysis of components of crested wheatgrass seed production. Agronomy Jr. 51: 515-518

Frederique, P., Stephanie, H., Ximena, M., Gerard, B., Dominique, F., Patricio, H. and Didier, M. (2010). An extensive study of the genetic diversity within seven French wine grape variety collections. Theoret. Appl. Gene. 120: 1219-1231

Galet, P. (2000). Dictionnaire encyclopédique des cépages. Hachette, Paris.

Gupta, N., Brar, K.S., Gill, M.I.S. and Arora, N.K. (2015). Studies on variability, correlation and path analysis of traits contributing to fruit yield in grapes. Indian $J r$. Plant Gene. Reso. 28(3): 317-320

Jolden, T. (2012). A sociological study of society in Ladakh: An anthropological overview. Res. Expo Internat. Multidisciplinary Res. Jr. 2(2): 38-49.

Joshi, V.,Kumar, V., Debnath, M., Pattanashetti, S., Variath, M.T. and Khadakabhavi, S.(2015). Multivariate analysis of colored and white grape grown under semi-arid tropical conditions of peninsular India. Internat. $J$. Agri. Crop Sci. 8(3): 350-365.

Kliewer, W.M. and Dokoozlia, N. (2000). Leaf area/crop weight ratio of grapevines. Influence on fruit composition and wine quality. Proc. Ameri. Soc. Enol. and Viticulture pp. 285-295.

Kumar, R., Rajan, S., Negi, S.S. and Yadava, L.P. (2002). Genetic variability in early ripening grape genotypes. Jr. Appl. Horti. 4: 118-120

Maul, E. and Eibach, R. (2003). Vitis international variety catalogue. http://www.genres.de/eccdb/vitis

NHB. (2015). Indian Horticulture Database 2014 www.nhb.gov.in

Obasi, M.O. (1992). Yield and yield component analysis in ground bean. E. Afri. Agric. For. Jr. 58(1): 13-18

Singh, B.D. (2003). Genetics. pp 223-228, Kalyani Publishers, New Delhi. 